\title{
HAND FUNCTION IN CHILDREN WITH MYELOMENINGOCELE
}

\author{
A. TURNER
}

\author{
From the Royal Liverpool Hospital, Liverpool
}

\begin{abstract}
Hand function in 33 patients with myelomeningocele, aged from 4 to 17 years, was investigated by clinical examination and formal tests of co-ordination and dexterity. The average score for hand function was $59 \%$ of normal and only two children had clinically normal upper limbs. Twenty-eight patients (85\%) had cerebellar ataxia, either alone or combined with other abnormal signs, most commonly upper motor neuron lesions.

Hand function was significantly better in children of 11 years and older, in children under 11 with milder degrees of hydrocephalus, and in the younger children who were right-handed. Function was not shown to be better in those with lesions lower in the spine, nor in those with stable spines as has been previously reported. When co-ordination of the upper limb, manual dexterity and simultaneous movements of both arms were examined separately, these three were affected equally. Some abnormalities of hand function could be overcome by encouraging affected children to sit up and to practise skilful use of their hands as early in life as possible.
\end{abstract}

Hand function in children with myelomeningocele is usually thought to be normal except where the lesion is at the cervical level (Sharrard 1979; Frank and Fixsen 1980). This may be because the upper limbs of these children often look normal to casual inspection, and because attention is directed to the weightier problems of paraplegia, hydrocephalus and renal dysfunction. It is not always appreciated that these children suffer from a global malformation of the central nervous system of which the myelomeningocele itself is but one manifestation.

There are few detailed studies of this problem, but Sand et al. (1974) and Grimm (1976) found deviant hand function in such children. Anderson (1975), using a standard test of hand function, found that fine finger movements were particularly affected, as was the manipulation of small objects which required efficient release mechanisms and good hand and eye co-ordination. Both Rowland (1973) and Spain (1974) reported similar findings. Lorber (1972) studied 270 children with myelomeningocele and found one with hand problems due to syringomyelia and one with a cervical lesion who had clumsiness and weakness of one hand. MacKenzie and Emery (1971) found that simultaneous hand movement was particularly affected in children with cervical lesions, because of lack of cross-cord association fibres at the level of the lesion. Parsons (1972) found that fine voluntary hand movements were impaired and that many patients had a tremor.

A. Turner, BSc, MCh Orth, FRCS, FRCS Ed, Senior Lecturer in Orthopaedic and Accident Surgery

Royal Liverpool Hospital. Prescot Street, Liverpool L69 3BX. England.

( 1985 British Editorial Society of Bone and Joint Surgery $0301-620 \times 85 / 2060 \$ 2.00$
This subject is important, because these children will have to rely upon their hands to express themselves in writing and in other delicate movements, to help propel themselves, and in most cases to earn a living. For this reason the hand function of 33 children with myelomeningocele was investigated in detail by careful clinical examination and by formal tests of function.

\section{PATIENTS AND METHODS}

A total of 33 children from three schools for the physically handicapped were studied. There were 20 girls with a mean age of 12 years (range 4 to 17 years) and 13 boys who also had a mean age of 12 years (range 6 to 16 years). The children were chosen at random, but all had

Table I. Clinical details of 33 children. subdivided by age group

\begin{tabular}{|c|c|c|}
\hline - - - & Under 11 years & 11 years and over \\
\hline Boys & 4 & 9 \\
\hline Girls & 5 & 15 \\
\hline $\begin{array}{l}\text { Level of lesion } \\
\text { Thoracolumbar } \\
\text { Thoracolumbosacral } \\
\text { Lumbosacral } \\
\text { Lumbosacral and cervical }\end{array}$ & $\begin{array}{l}- \\
6 \\
1\end{array}$ & $\begin{array}{r}2 \\
10 \\
12 \\
-\end{array}$ \\
\hline $\begin{array}{l}\text { Progress of lesion } \\
\text { Satisfactory } \\
\text { Unsatisfactory }\end{array}$ & $\begin{array}{l}6 \\
3\end{array}$ & $\begin{array}{l}10 \\
14\end{array}$ \\
\hline $\begin{array}{l}\text { Handedness } \\
\text { Right } \\
\text { Left } \\
\text { No preference }\end{array}$ & $\begin{array}{l}6 \\
2 \\
1\end{array}$ & $\begin{array}{r}17 \\
7 \\
-\end{array}$ \\
\hline $\begin{array}{l}\text { Spine } \\
\text { Stable } \\
\text { Unstable }\end{array}$ & 9 & $\begin{array}{l}12 \\
12\end{array}$ \\
\hline
\end{tabular}


originally had open myelomeningoceles, 31 of which had been closed at birth; one had been closed late because of parental opposition and one had been allowed to close spontaneously. There were 18 lumbosacral, 12 thoracolumbosacral, 2 thoracolumbar and 1 double lesion. All the children had suffered hydrocephalus for which valves had been inserted between 10 days and 2 months after birth.

The patients were divided into two groups: those aged 10 years and under, and those aged 11 years and older. Results were analysed within these two groups. This age level was chosen arbitrarily, but subdivision was considered necessary because the older group would be more reliable witnesses, co-operate better in tests and show greater maturity of the central nervous system, all of which would affect the results. Clinical details for each age group are shown in Table I. Twelve children had severe kyphosis or lordoscoliosis, two had already undergone corrective spinal surgery, and 19 children had stable spinal columns. Twenty-two children were righthanded, nine were left-handed, one had changed to righthanded from left-handed after a left hemiparesis, and one had no hand preference. All the children spent most of their time in a wheelchair. Three had had fits in the past, none recently, and none was taking anticonvulsant drugs.

Hand function was assessed quantitatively by use of a modification of the test of motor impairment described by Stott, Moyes and Henderson (1972), which gave a percentage score showing how well the children used their hands. Three modalities of hand function were examined at age levels varying from under 5 years to over 13 years. These were control and co-ordination of the upper limbs, manual dexterity with emphasis on speed, and tasks emphasising simultaneous movements and precision. The tests used at various ages are given in Table II.

Each child was first tested at his own age level in each of the three modalities. When each hand was tested separately, two points were scored when both hands passed, and one if the child succeeded with only one hand. For simultaneous hand movement two points were scored for success and none for failure. Thus when a child passed all the tests at one age level he scored six points. If a child failed any test at his own age level he was tested at lower levels until he passed all the tests at one age level. Addition of all the points scored, assuming success below the last level, gave a score which indicated how well the child could use his hands. This score was expressed as a percentage of the points obtainable for normal function at that age.

The method of scoring can be illustrated by two examples. A 10-year-old child who failed all the tests at his age level and tests at the lower age levels including those for the under-fives, would have been tested at seven age levels (Table II) and would have failed to score at each. The total score for normal function at this age
Table II. Summary of the tests used to assess three types of hand function at various ages

\begin{tabular}{|c|c|c|c|}
\hline \multirow[b]{2}{*}{$\begin{array}{l}\text { Age } \\
\text { (years) }\end{array}$} & \multicolumn{3}{|c|}{ Test of hand function } \\
\hline & Co-ordination & $\begin{array}{l}\text { Manual } \\
\text { dexterity }\end{array}$ & $\begin{array}{l}\text { Simultaneous } \\
\text { movements }\end{array}$ \\
\hline 13 and over & $\begin{array}{l}\text { Ring and } \\
\text { coathanger }\end{array}$ & Track rotating & Piercing \\
\hline $11-12$ & Hitting target & Piercing holes & Pegs and squares \\
\hline 10 & $\begin{array}{l}\text { Guiding ball } \\
\text { among tees }\end{array}$ & Matchboxes & Squares \\
\hline 9 & $\begin{array}{l}\text { Catching with } \\
\text { one hand }\end{array}$ & 9-hole board & Pegs \\
\hline 8 & $\begin{array}{l}\text { Catching ball } \\
\text { off wall }\end{array}$ & Lacing board & $\begin{array}{l}\text { Bead on board } \\
\text { balance* }\end{array}$ \\
\hline 7 & Spiral of holes & $\begin{array}{l}\text { Placing pegs in } \\
\text { board }\end{array}$ & $\begin{array}{l}\text { Fingertip } \\
\text { touching }\end{array}$ \\
\hline 6 & $\begin{array}{l}\text { Bouncing and } \\
\text { one-hand catch }\end{array}$ & Threading beads & Circle trace \\
\hline 5 & $\begin{array}{l}\text { Bouncing and } \\
\text { two-hand catch }\end{array}$ & Posting coins & $\begin{array}{l}\text { Markers } \\
\text { (counters) }\end{array}$ \\
\hline Under 5 & Bridge of rods & 12-pin board & Matchsticks \\
\hline
\end{tabular}

* This test involved standing and could not be used for our patients.

would have been six points at each of seven levels, that is, 42 points. The hand function score for this patient would be $0 / 42 \times 100=0 \%$. If another 10-year-old child, failing all tests for seven-year olds, had passed all tests at the sixyear level, it would be assumed that he would pass all the tests at the five and under-five levels, and he would score six points at each of the three levels, that is, 18 points. As the maximum possible points for a 10-year-old are 42 , this child would score $18 / 42 \times 100=43 \%$.

The progress of the hydrocephalus in each child was assessed from clinical records by plotting head circumference against age (Fig. 1). Progress was then designated as satisfactory if the line obtained remained below the 90 th centile for head circumference for most of its course, or unsatisfactory if it was mostly above this line.

Clinical assessment of upper limb symptoms, squint, nystagmus,the special senses and intelligence was made and a full neurological examination of the upper limbs was performed.

Hand function scores were then related to age, sex, level of the lesion, progress of hydrocephalus, spinal stability, handedness, upper limb symptoms and signs and the presence of squint and nystagmus.

Figures were compared directly, using mean values, and were also subjected to statistical analysis. To determine the statistical significance of the difference between two groups of figures, for example hand function in groups with stable and unstable spines, the standard error of the difference between means was calculated and divided into the actual difference between the means. This gave a statement of probability related to multiples of the standard error. To discover possible 
correlation between two sets of figures, for example between hand function and increasing age, the correlation coefficient was calculated (Swinscow 1983).

\section{RESULTS}

The results were not analysed in terms of handedness since this would have made them unwieldy, though of course the children performed better with their preferred hand. The mean hand function percentages are shown in Table III; it is seen that the mean score for the whole group was only $59 \%$. Taking all ages of children, hand function was marginally better in girls, and in those with neither a squint nor nystagmus. Hand function also appeared slightly better in those with unsatisfactory progression of hydrocephalus, with spinal instability, in left-handed children and in those who had arm symptoms. In none of these cases, however, were the differences statistically significant. There was no correlation between either the extent or level of the spinal lesion and scores of hand function.

Analysis of the results within the two age groups revealed that three differences were statistically significant (Table III): hand function was better in the older group, it was better in the younger children with satisfactory progression of hydrocephalus, and it was better in the younger children who were right-handed.

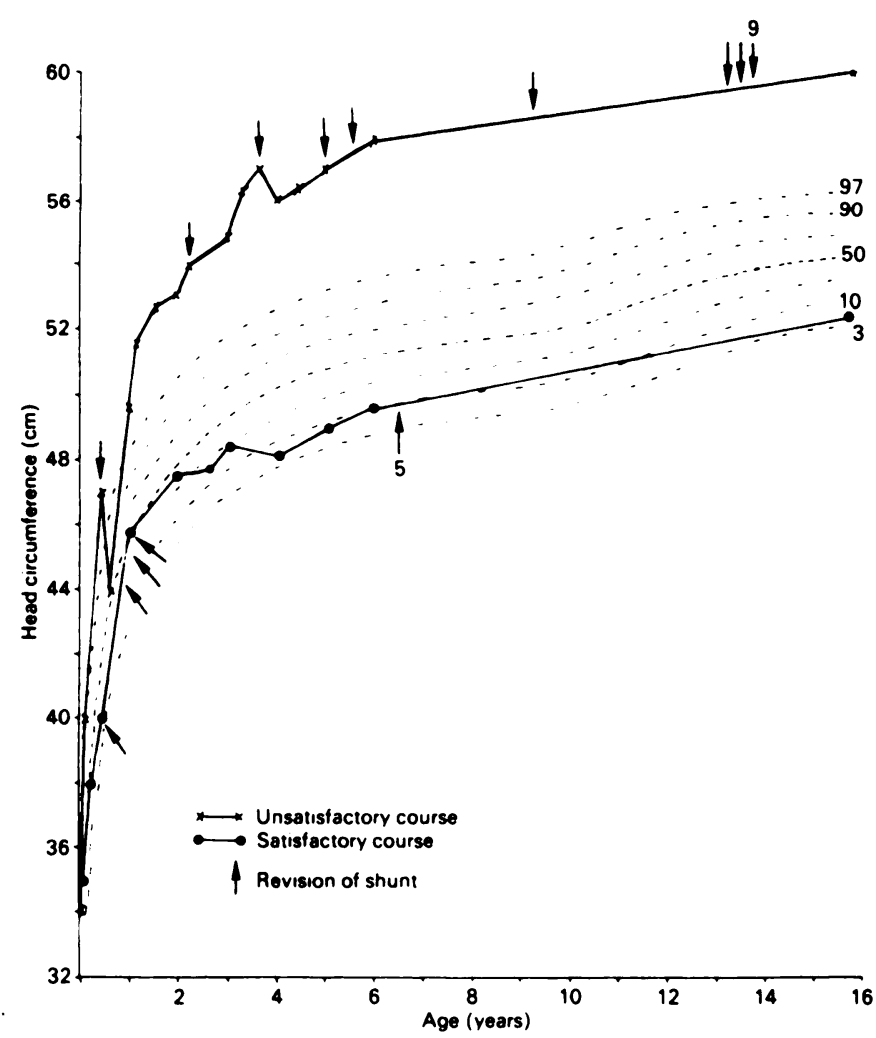

Fig. 1

Examples of head circumference charts on a centile scale of normals, to show the unsatisfactory course of one patient who had nine shunt revisions and the satisfactory course of another after five shunt revisions.
Table III. Mean scores for hand function related to age and to various subgroupings

\begin{tabular}{|c|c|c|c|}
\hline \multirow[b]{2}{*}{ Subgroups } & \multicolumn{3}{|c|}{ Mean score for hand function (\%) } \\
\hline & $\begin{array}{l}\text { All age } \\
\text { groups }\end{array}$ & $\begin{array}{l}\text { Under } \\
11 \text { years }\end{array}$ & $\begin{array}{l}11 \text { years } \\
\text { and over }\end{array}$ \\
\hline All children & 59 & $\begin{array}{l}20 \\
(P<0.001)\end{array}$ & 74 \\
\hline $\begin{array}{l}\text { Girls } \\
\text { Boys }\end{array}$ & $\begin{array}{l}60 \\
57\end{array}$ & $\begin{array}{l}10 \\
34\end{array}$ & $\begin{array}{l}78 \\
67\end{array}$ \\
\hline $\begin{array}{l}\text { Level of lesion } \\
\text { Thoracolumbar } \\
\text { Thoracolumbosacral } \\
\text { Lumbosacral }\end{array}$ & $\begin{array}{l}48 \\
76 \\
52\end{array}$ & $\begin{array}{l}\overline{56} \\
12\end{array}$ & $\begin{array}{l}48 \\
80 \\
72\end{array}$ \\
\hline $\begin{array}{l}\text { Progress of hydrocephalus } \\
\text { Satisfactory } \\
\text { Unsatisfactory }\end{array}$ & $\begin{array}{l}57 \\
64\end{array}$ & $\begin{array}{l}28 \\
0 \\
(P<0.05)\end{array}$ & $\begin{array}{l}75 \\
73\end{array}$ \\
\hline $\begin{array}{l}\text { Spine } \\
\text { Stable } \\
\text { Unstable }\end{array}$ & $\begin{array}{l}52 \\
71\end{array}$ & 20 & $\begin{array}{l}75 \\
72\end{array}$ \\
\hline $\begin{array}{l}\text { Handedness } \\
\text { Right } \\
\text { Left }\end{array}$ & $\begin{array}{l}57 \\
65\end{array}$ & $\begin{array}{l}25 \\
6 \\
(P<0.04)\end{array}$ & $\begin{array}{l}71 \\
82\end{array}$ \\
\hline $\begin{array}{c}\text { Arm symptoms } \\
\text { Nil } \\
\text { Present }\end{array}$ & $\begin{array}{l}47 \\
68\end{array}$ & $\begin{array}{l}11 \\
48\end{array}$ & $\begin{array}{l}80 \\
71\end{array}$ \\
\hline $\begin{array}{l}\text { Squint } \\
\text { Present } \\
\text { Nil }\end{array}$ & $\begin{array}{l}51 \\
65\end{array}$ & $\begin{array}{l}22 \\
18\end{array}$ & $\begin{array}{l}68 \\
78\end{array}$ \\
\hline $\begin{array}{l}\text { Nystagmus } \\
\text { Present } \\
\text { Nil }\end{array}$ & $\begin{array}{l}58 \\
62\end{array}$ & $\begin{array}{r}27 \\
7\end{array}$ & $\begin{array}{l}70 \\
83\end{array}$ \\
\hline
\end{tabular}

$P$ values are only given where they are statistically significant.

Clinical symptoms were non-specific and never severe or distressing. They included clumsiness, paraesthesia and numbness, weakness, and difficulty in using a typewriter. Clinical signs, together with the mean score for each group of signs, are shown in Table IV. There was no correlation between hand function and the clinical signs. The three components of hand function which were tested separately were plotted against total hand function (Fig. 2) and showed that each one tended to deteriorate in parallel with the other two.

\section{DISCUSSION}

The testing of hand function is fraught with difficulty because little research has been done on motor function and there are many variables which influence the performance of the tests and the results. Few standardised tests of hand function are available, particularly for younger children. The Stott, Moyes and Henderson (1972) test of motor impairment is one method. This group of tests is constructed so as to exclude all reasons for failure other than motor function. The point of failure of each test is set at a level of impairment which would handicap a child 
in everyday activities and needs, such as playing games with his own age group, avoiding accidents to himself or to objects which he handles and developing skills like writing and using tools.

The main conclusion reached from the study was that hand function in these children was markedly affected, with the mean score for all 33 being only $59 \%$. Function was better in the older children, possibly because they co-operated better (though the construction of the tests should eliminate this bias), or because of the greater maturity of their nervous system. Also, there were more girls than boys in the older age group (Table I) and girls seemed to do better anyway.

No definite correlation was found between the level or extent of the spinal lesion and hand function. Indeed, those with the more extensive spinal lesions seemed to perform better although the difference was not statistically significant. Hand function has been reported to be worse with lesions higher in the spinal cord (Grimm 1976), but Minns et al. (1977) found that the level of the lesion bore no relationship to practical difficulties with the upper limb.

Hand function is usually considered to be better in children with stable spines (Hunt 1973) and in those with less severe hydrocephalus (Grimm 1976). These conclusions are not supported by this study, except in the case of the younger group of children where hand function was found to be significantly better in those with milder hydrocephalus.

Nine of the 33 patients $(27 \%)$ were left-handed whilst one $(3 \%)$ had no preference. The percentage of
Table IV. Classification of clinical signs found in the arm, with number of patients and average of hand function scores

\begin{tabular}{|c|c|c|}
\hline Clinical signs & $\begin{array}{l}\text { Number of } \\
\text { patients }\end{array}$ & Average score (\%) \\
\hline Normal & 2 & 96 \\
\hline $\begin{array}{l}\text { Cerebellar ataxia with UMN lesion } \\
\text { and } L M N \text { lesion }\end{array}$ & 1 & 93 \\
\hline $\begin{array}{l}\text { Cerebellar ataxia with bilateral } \\
\text { UMN lesion }\end{array}$ & 9 & 70 \\
\hline Cerebellar ataxia alone & 9 & 62 \\
\hline $\begin{array}{l}\text { Cerebellar ataxia with unilateral } \\
\text { UMN lesion }\end{array}$ & 7 & 49 \\
\hline Bilateral UMN lesion & 2 & 48 \\
\hline Unilateral UMN lesion & 1 & 38 \\
\hline $\begin{array}{l}\text { Cerebellar ataxia with bilateral } \\
\text { UMN lesion and athetoid } \\
\text { movements }\end{array}$ & 2 & 4 \\
\hline
\end{tabular}

Nystagmus was present in 21 of the 28 patients who had cerebellar ataxia.

UMN, upper motor neuron

LMN, lower motor neuron

left-handed people in the normal population varies with age, but Belmont and Birch (1963) reported figures of between $3 \%$ and $12 \%$ in "bright, normal children". The proportion of left-handed children in this study would thus seem to be well above the average. Overall, lefthanded children scored better in hand function tests than those who were right-handed. But in the younger group the right-handed children had rather better results, the figures being statistically significant.

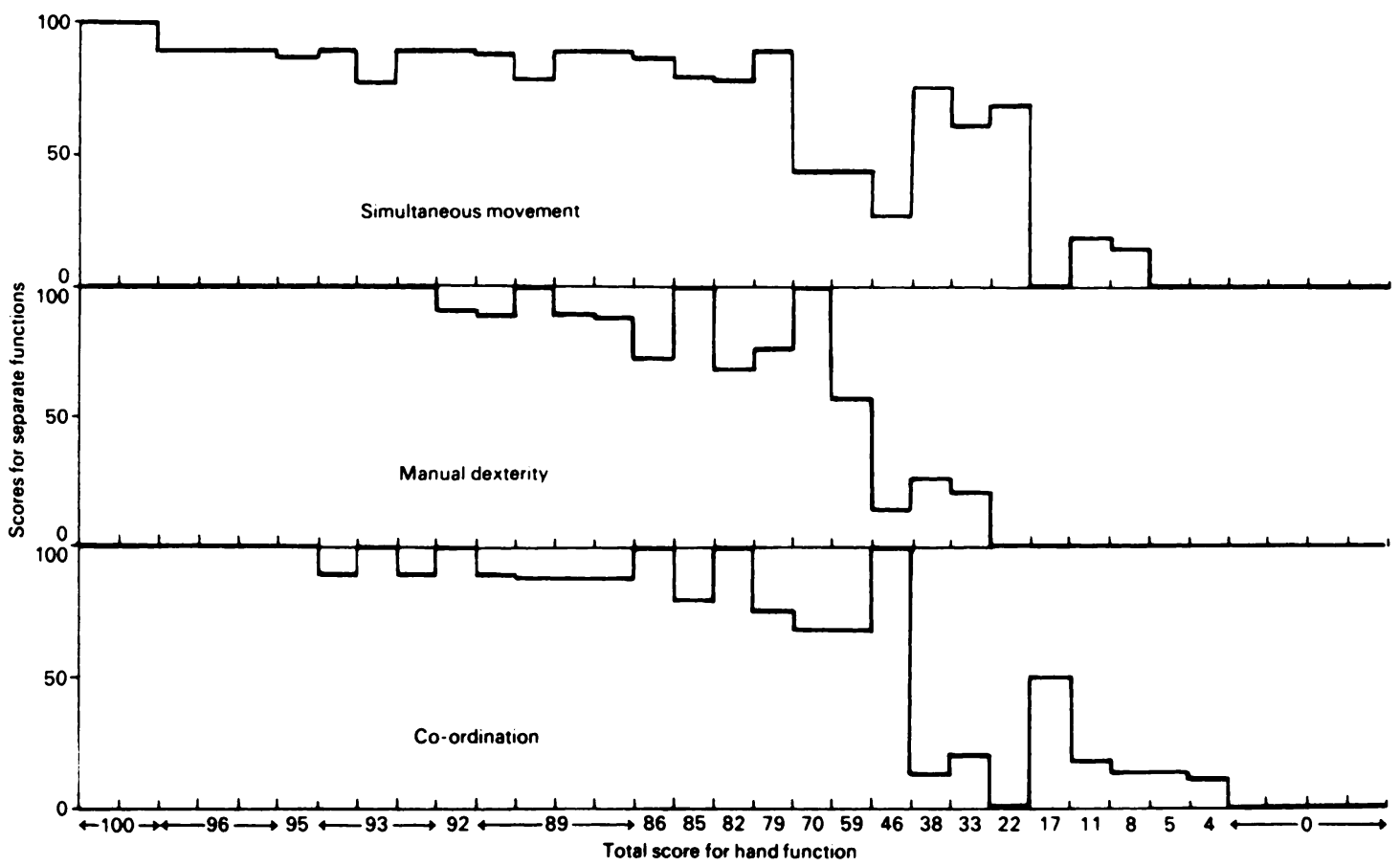

Fig. 2

Chart to show the relation of the scores for the three separate groups of tests for hand function to the total score for each child. As all figures are percentages of the normal score possible for the separate test or for total function, the sum of the separate scores has to be divided by three to obtain the total score. There is no significant difference between groups or between each group and the total score. 
The establishment of hand preference is complex but has major importance in development. It is fully reviewed by Anderson and Spain (1977). It is generally agreed that there is a lower proportion of purely righthanded patients and an abnormally high proportion of those who are left-handed or mixed handed among the population with myelomeningocele (Anderson 1975). The reasons why many such children fail to establish a clear hand preference are probably related to damage to the central nervous system, and specifically to the corpus callosum, with absence of proper lateralisation and lack of establishment of a preference for the use of one side of the body.

Fourteen children $(42 \%)$ had a squint. This could affect hand function, which tended to be better in the non-squint group although the difference was not statistically significant. Alberman. Butler and Gardiner (1971) reported that children with a squint tended to perform worse in reading and other tests involving vision. Twenty-two children (67\%) had nystagmus and although the score for hand function was marginally better in the group without nystagmus, the difference was not statistically significant. This could be regarded as surprising since nystagmus may be an indication of cerebellar dysfunction or of an abnormality of its connections with the brain stem and the vestibular nuclei.
Although scores for hand function could not be correlated with the types of neurological sign present, it was found that the three tested components of hand function, co-ordination, manual dexterity and simultaneous movements all tended to deteriorate in parallel as hand function worsened. This contrasts with the results of MacKenzie and Emery (1971), who found that simultaneous movements of the hands were worse affected than manual dexterity or co-ordination.

Conclusions. Hand function may be considerably impaired in children with myelomeningocele. This observation is of value because hand function may be improved by encouraging these children to practise their hand skills as early and as often as possible. Anderson and Spain (1977) have pointed out that activities which will help to develop visual awareness, body and tactile awareness, hand and eye co-ordination and general use of the hands should be encouraged from the start. This will help to overcome many of the difficulties these children have with hand function-a goal which the author feels is well worth attaining.

My grateful thanks are due to Professor Robert Owen for his constant encouragement and help in carrying out this work, and for suggesting that this would be a useful topic to study. I would like to thank Mrs G. L. Berry for typing the manuscript and Mrs E. Brandwood for drawing the figures.

\section{REFERENCES}

Alberman ED, Butler NR, Gardiner PA. Children with squints: a handicapped group? Practitioner 1971;206:501-6.

Anderson EM. Cognitive and motor deficits in children with spina bifida and hydrocephalus with special reference to writing difficulties. Unpublished PhD Thesis. University of London. 1975.

Anderson EM, Spain B. The child with spina bifida. London: Methuen \& Co. Ltd, 1977.

Belmont L, Birch HG. Lateral dominance and right-left awareness in normal children. Child Dev 1963:34:257-70.

Frank JD, Fixsen JA. Spina bifida. Br J Hosp Med 1980;24:422-37.

Grimm RA. Hand function and tactile perception in a sample of children with myelomeningocele. Am J Occup Ther 1976; 30(4):234-40.

Hunt GM. Implications of the treatment of myelomeningocele for the child and his family. Lancet 1973;ii:1308-10.

Lorber J. Spina bifida cystica: results of treatment of 270 consecutive cases with criteria for selection for the future. Arch Dis Child 1972:47:854-73.

MacKenzie NG, Emery JL. Deformities of the cervical cord in children with neurospinal dysraphism. Dev Med Child Neurol 1971;13 Suppl 25:58-67.
Minns RA, Sobkowiak CA, Skardoutsou A, et al. Upper limb function in spina bifida. $Z$ Kinderchir 1977:22(4):493-506.

Parsons JG. Assessments of aptitudes in young people of schoolleaving age handicapped by hydrocephalus or spina bifida cystica. Dev Med Child Neurol (Suppl) 1972;14 Suppl 27:101-8.

Rowland M. Evaluation of play group for children with spina bifida Social Work Today. 1973:4(11):324-30.

Sand PL, Taylor N, Hill M, Kosky N, Rawlings M. Hand function in children with myelomeningocele. Am $J$ Occup Ther 1974;28: 87-90.

Sharrard WJW. Paediatric orthopaedics and fractures. 2nd ed. Oxford, London. Edinburgh, Melbourne: Blackwell Scientific Publications, 1979:2:1121.

Spain B. Verbal performance ability in pre-school children with spina bifida. Dev Med Child Neurol 1974:16(6):773-80.

Stott DH, Moyes FA, Henderson SE. Test of motor impairment. Guelph, Ontario: Brook Educational, 1972.

Swinscow TDV. Statistics at square one. 8th ed. London: British Medical Association. 1983. 